\title{
PRODUKSI SERIAL ANIMASI 3D JAMBUL
}

\author{
Ardiyansah \\ Desain Komunikasi Visual, School of Design, BINUS University \\ Jln. K. H. Syahdan No. 9, Palmerah, Jakarta Barat 11480 \\ sah@binus.ac.id
}

\begin{abstract}
Jambul is a 3D animated series initiated by Animaraya, an animation studio located in South Jakarta. Taking the theme of daily lives of a bunch of kids in Maju Makmur village with all love, sorrow, and their dreams, the series has a typical look with common theme raised by other local animation producers. Nevertheless, the presence of serial Jambul must still be in the positive appreciation by both the animation industry, and in general by the people of Indonesia. In addition, because of this series appeared in all the limitations, Jambul showed up with a new standard for animated series production in Indonesia, especially in terms of production efficiency, time, cost, stories, and visual quality.
\end{abstract}

Keywords: Jambul series, 3D animation

\begin{abstract}
ABSTRAK
Jambul adalah serial animasi 3D yang diprakarsai oleh Animaraya, sebuah studio animasi yang berlokasi di wilayah Jakarta Selatan. Mengambil tema tentang keseharian sekumpulan anak di desa Maju Makmur dengan segala suka, duka, dan impiannya, serial ini menjadi tampak tipikal dengan tema yang lazim diangkat oleh produser animasi lokal lainnya. Meskipun demikian, kehadiran serial Jambul ini tetap harus di apresiasi positif baik oleh para pelaku industri animasi, maupun secara umum oleh masyarakat Indonesia. Selain karena serial ini muncul di tengah segala keterbatasan, Jambul muncul dengan membawa standar baru bagi produksi serial animasi di Indonesia, terutama dari sisi efisiensi produksi, waktu, biaya, penggarapan cerita, dan kualitas visual.
\end{abstract}

Kata kunci: Serial Jambul, Animasi 3D 


\section{PENDAHULUAN}

Kita telah sering mendengar bagaimana sebuah karya animasi produksi dalam negeri awalnya dikabarkan dengan penuh gegap gempita seolah menjadi keberhasilan nasional, tetapi kemudian harus berakhir tragis dengan komentar sinis bahkan caci maki karena ternyata gagal memenuhi ekspektasi publik. Sebagai contoh, rencana produksi film layar lebar tentang Pangeran Diponegoro harus gagal total karena mendapat sorotan justru dari masyarakat yang sudah menunggu-nunggu lahirnya produk animasi nasional. Hal ini membuktikan bahwa embel-embel "karya anak bangsa" sudah tidak mampu lagi menjadi alasan produser untuk boleh menciptakan animasi secara asal-asalan. Penonton saat ini sudah tidak bisa ditipu dengan jargon-jargon yang lebih banyak dipakai sebagai bagian dari strategi pemasaran. Untuk itu, sebuah keputusan bijak dari produser Jambul dengan tidak melakukan publikasi maupun klaim secara berlebihan. Biar masyarakat sendiri yang menilai.

Ide tentang pembuatan serial animasi Jambul ini tak lepas dari upaya untuk menghidupkan industri animasi nasional dengan tetap mengusung tema lokalitas. Kenapa lokal? Agar serial animasi ini nantinya dapat memberikan gambaran yang lebih dekat dengan konteks pengetahuan dan pemahaman budaya masyarakat Indonesia, sehingga setiap pesan yang disampaikan dapat ditangkap dengan lebih mudah. Selain isu lokalitas, serial Jambul juga berkomitmen menyuguhkan animasi Indonesia dengan kualitas visual yang lebih baik. Untuk itulah perencanaan dilakukan dengan melakukan berbagai riset dan pengumpulan data secara sederhana namun akurat. Termasuk di dalamnya implementasi prinsip-prinsip fotografi dan sinematografi untuk menghasilkan kualitas gambar sebaik mungkin.

Awalnya tidak mudah menentukan setting yang dapat mewakili Indonesia secara utuh. Karena seperti kita tahu, Indonesia terlalu luas dan beragam untuk dapat diwakili oleh sebuah tafsir tunggal. Setelah melalui berbagai macam pertimbangan, maka dipilihlah Muntilan, kota kecamatan di wilayah Kabupaten Magelang yang berdekatan dengan Jogjakarta sebagai setting. Alasannya, selain lebih terjangkau untuk kepentingan pengumpulan data dan referensi, Muntilan juga merupakan jalur perjalanan wisata menuju Candi Borobudur dan Gunung Merapi. Kedua landmark ini diharapkan bisa menjadi daya tarik tersendiri apabila bisa dimunculkan dalam animasi tersebut. Juga kondisi alam dan lingkungannya yang masih relatif terpelihara menjadikan tempat ini sempurna sebagai setting animasi yang bercerita tentang kehidupan anak-anak desa. Setelah semua ide dan materi awal terkumpul, barulah kemudian tim dibagi dalam divisi-divisi dengan tanggung jawab dan peran masing-masing.

\section{METODE PENELITIAN}

Penelitian dilakukan dengan melakukan studi lapangan untuk mendapatkan referensi aktual dan akurat sesuai pengembangan setting yang ingin dicapai, diikuti dengan serangkaian studi literatur dan informasi yang mendukung, sehingga kemudian diperoleh data-data yang diperlukan untuk pembuatan model atau replika digital dari objek-objek yang relevan dalam konteks penelitian ini.

\section{HASIL DAN PEMBAHASAN}

Serial Jambul bercerita tentang sekumpulan anak desa Maju Makmur, sebuah desa imajiner dengan latar belakang landmark Candi Borobudur dan Gunung Merapi. Sebuah desa yang digambarkan memiliki lingkungan yang masih sejuk dan asri dengan kehidupan sosial masyarakat yang tenteram. 
Serial Jambul mengangkat "local content” dengan kualitas visual yang menarik. Hal ini dapat dilihat terutama pada scene yang menampilkan persawahan dengan latar belakang alam yang masih asri, bentuk rumah dan suasana pemukiman yang digambarkan mendekati keadaan yang sebenarnya dengan mengambil referensi daerah Muntilan, serta penokohan yang dibuat aktual dengan kondisi dan konteks pemahaman anak jaman sekarang.

Serial ini banyak bercerita tentang kehidupan sehari-hari anak desa Maju Makmur yang dipimpin oleh si Jambul, bocah periang yang sebelumnya tinggal di kota dan terpaksa pindah ke desa tersebut karena mengikuti ayahnya yang bekerja sebagai seorang pegawai pemerintah.

Jambul dikenal sebagai anak yang cerdas dan tahu banyak hal. Selain karena kegemarannya membaca, sifat Jambul yang selalu ingin tahu dan latar belakangnya yang pernah tinggal di kota membuat dia tahu beberapa hal yang belum diketahui teman-temannya. Hal inilah yang membuat Bagong, Momo, Jingga, Marco, dan Laila senang berteman dengannya.

Namun, Jambul punya satu kebiasaan buruk. Yaitu, mudah sekali tidur di mana saja dan kapan saja sehingga oleh teman-temannya sering menjadi bahan bercandaan. Justru kebiasannya tidur (dan kemudian bermimpi) inilah yang mengantarkan Jambul dan kawan-kawannya mengalami petualangan-petualangan seru dan penuh imajinasi.

Cerita-cerita dalam serial ini tidak hanya mengajak anak untuk bermain-main, tetapi juga belajar menghormati alam dan lingkungan. Serial ini berusaha memasukkan unsur education for sustainable development, hard skill, soft skill, dan enterpreneurship berbasis lokalitas dengan tetap mempertahankan fungsi utamanya sebagai hiburan.

\section{Sinopsis Episode 1}

Jingga medapat hadiah dari pamannya berupa perangkat game portable, tetapi karena dia tidak terlalu bisa memainkannya maka dia meminta bantuan Momo dan Bagong yang kebetulan sedang bermain-main di dekat rumahnya.

Bagong yang sok tahu merasa bisa memainkannya, tetapi ternyata dia bahkan tidak bisa membedakan perangkat game tersebut dengan HP. Momo dan Jingga yang kesal kemudian sepakat untuk menanyakan soal game itu kepada Jambul. Mereka beranggapan Jambul pasti pernah memainkan peralatan ini ketika dulu di kota.

Sesampainya di rumah Jambul, bocah berkacamata ini menunjukkan cara bermainnya, tetapi dia mengatakan bahwa game semacam itu hanya bisa asyik sendiri dan tidak bisa untuk ramai-ramai. Akhirnya si Momo mencetuskan ide untuk bermain perang-perangan saja. Dan Jambul kemudian menambahkan untuk membuat senjatanya dari pelepah daun pisang. Maka mereka kemudian berbagi tugas. Jambul menyiapkan peta peperangan. Bagong dan Momo mencari pelepah daun pisang dengan dibantu Marco. Sementara Jingga menjemput Laila untuk diajak menjadi perawat dalam permainan perang-perangan tersebut.

Setelah semuanya siap, mereka memulai permainannya. Siapa yang lebih dulu mencapai tiang bendera di sekolah maka kelompok itulah yang menang. Kelompok Momo, Bagong, dan Jingga kemudian melewati jalur yang becek sehingga Jingga tak henti-hentinya mengeluh, bahkan Bagong akhirnya terantuk batu dan tercebur bersimbah lumpur. Akan tetapi, kelompok ini akhirnya menang karena mereka akhirnya sampai lebih dulu.

Sementara kelompok Jambul, Marco, dan Laila justru tertinggal karena Jambul tertidur pulas dan Marco asyik bermain bola ketika istirahat. Meskipun kelompok ini akhirnya kalah, justru 
merekalah yang bisa tertawa-tawa karena melihat kelompok lawannya berwajah lesu di bawah tiang bendera.

Acara perang-perangan gagal total, tetapi itu tak menghalangi kegembiraan mereka. Laila berhasil meyakinkan teman-temanya bahwa bermain tak harus selalu soal menang dan kalah. Anakanak ini setuju dan mereka akhirnya melanjutkan bermain kejar-kejaran di sekolah. Kali ini Bagong si gendut yang harus lari menghindari keisengan teman-temannya.

\section{Proses Produksi}

Sebagaimana yang terdapat dalam tulisan terdahulu berjudul "Cinema 4D Dalam Pipeline Produksi Serial Animasi,” maka proses produksi serial animasi (3D) meliputi:

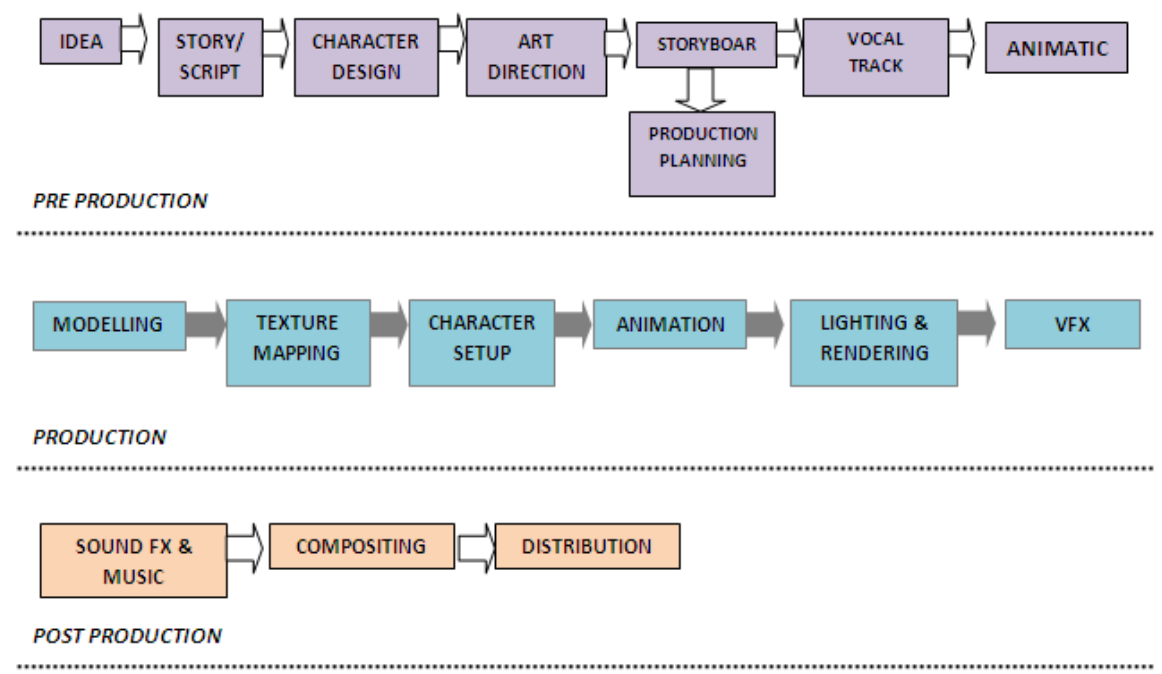

Gambar 1 Pipeline Produksi Animasi

\section{Desain Karakter}

Desain karakter (dan environment) bisa dilakukan setelah ide cerita dan konsep telah benarbenar matang dan disepakati oleh pihak-pihak terkait. Desain karakter dimulai dengan membuat sketsa, model sheet, dan kemudian gesture termasuk memberikan detail ekspresi sebagai acuan ketika telah memasuki proses modeling.

Berikut adalah contoh desain karakter yang masih berupa sketsa:

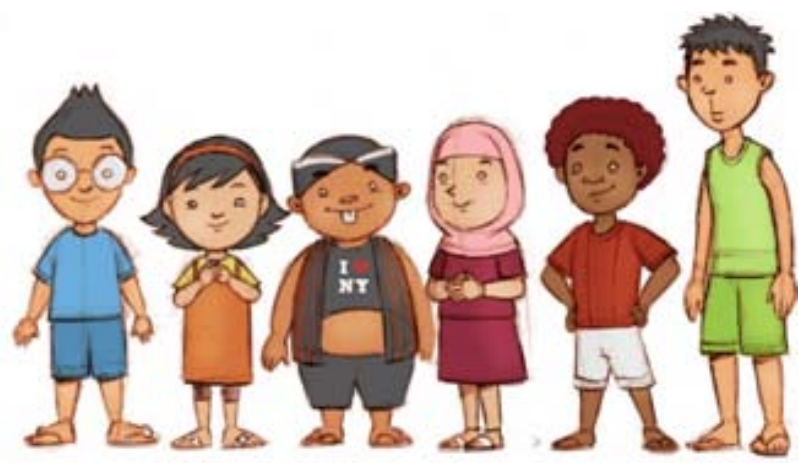

Gambar 2 Character Design/Comparison 

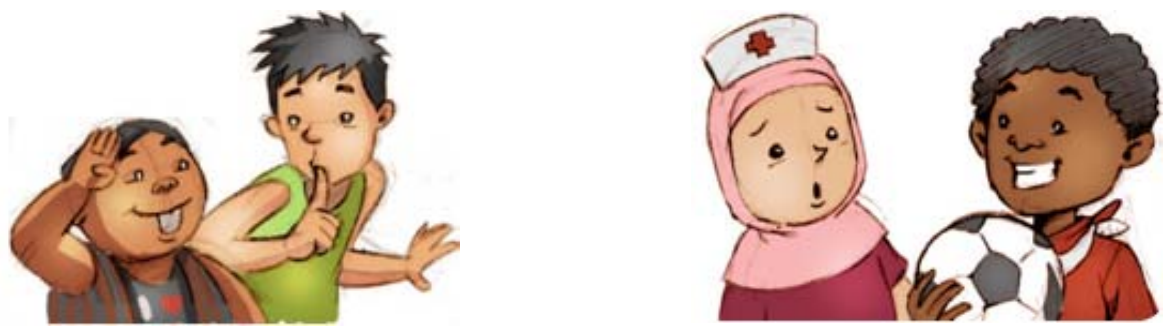

Gambar 3 Gesture/Expression

Dalam konteks pekerjaan desain karakter, juga meliputi penjelasan yang detail mengenai sifat, sikap, hobby dan sebagainya yang mendukung personifikasi karakter. Berikut adalah penjelasan masing-masing karakter berikut hasil visualisasi karakter setelah di-model:

\section{Jambul}

Jambul sebelumnya tinggal di kota, tetapi karena ayahnya yang pegawai pemerintah dipindahkan ke desa Maju Makmur (yang kebetulan juga tempat tinggal kakek neneknya), mau tidak mau dia harus mengikuti ayahnya. Jambul dikenal cerdas dan punya segudang ide. Kegemarannya membaca ditambah rasa ingin tahunya selalu mendorongnya menemukan hal-hal menarik yang kemudian sering berubah menjadi petualangan. Jambul jago dalam urusan matematika dan ilmu alam, dia sering kali melakukan eksperimen sains dengan memanfaatkan barang-barang yang ada di sekitarnya. Jambul juga memanfaatkan keahliannya untuk membuat mainannya sendiri, sebab dia berasal dari keluarga sederhana yang tidak memungkinkannya selalu membeli mainan dengan meminta kepada orang tua. Karena kegemarannya membaca buku hingga larut malam, Jambul menjadi mudah mengantuk, di mana saja dan dalam posisi apa saja, Jambul dengan mudah bisa terlelap. Dalam tidurnya Jambul sering kali bermimpi, bertemu, dan berkomunikasi dengan tokohtokoh fantasi dalam buku-bukunya. Sebuah awal petualangan yang seru.

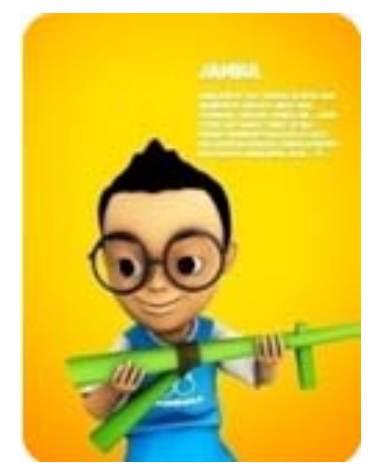

Gambar 4 Karakter Jambul

\section{Marco}

Marco adalah penggemar sepak bola, hampir semua informasi yang berhubungan dengan olahraga ini dia ketahui. Update berita tentang skor pertandingan dan transfer pemain di liga-liga top dunia dan lokal tak luput dari perhatiannya, dan Marco memang jago untuk urusan menggocek bola. Selain itu Marco mempunyai kegemaran lain di bidang tarik suara. Dia dianugerahi suara yang sangat indah dan kemampuan memainkan alat musik. Teman-temannya senang karena merasa terhibur 
dengan keahliannya tersebut. Kedua orang tua Marco berasal dari Ambon dan kebetulan sedang mencari nafkah di Desa Maju Makmur.

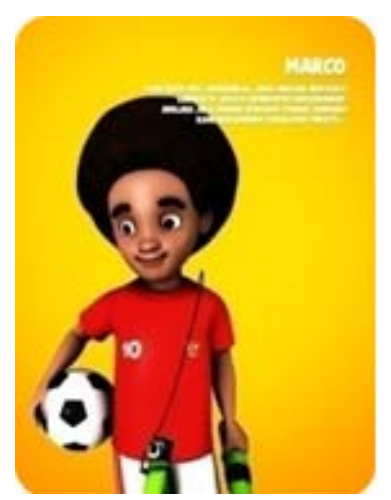

Gambar 5 Karakter Marco

\section{Bagong}

Bagong adalah representasi anak kampung yang divisualisasikan secara harfiah, mengenakan blangkon, surjan, dan ikon-ikon budaya (Jawa) membuatnya menjadi unik di antara kawan-kawannya yang lain. Secara umum, sifatnya kocak, lucu, lugu, sok tahu dan di setiap penampilannya selalu menghibur. Badannya yang tambun dan gaya bahasanya yang lucu membuat dia disukai kawan-kawannya. Bahkan ketika menjadi objek lelucon, Bagong tetap "tabah", dan tetap mengundang orang untuk tertawa. Satu hal yang menjadi kelemahan Bagong adalah sifatnya yang penakut, terutama untuk hal-hal yang berbau takhayul.

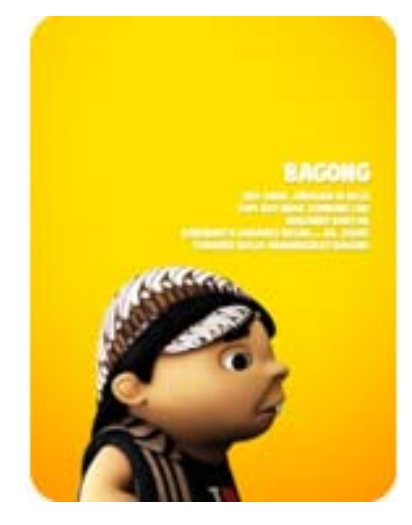

Gambar 6 Karakter Bagong

\section{Momo}

Momo (atau yang sering dilafalkan sebagai Momok) tergolong anak yang usil dan suka mengerjai teman-temannya. Dia suka sekali menggoda Bagong dan Jingga. Meskipun demikian, dia tidak dibenci oleh teman-temannya karena justru Momolah yang seringkali melindungi temantemannya dalam keadaan-keadaan berbahaya. Momo tidak terlalu pintar, dia juga bukan berasal dari keluarga yang berlebihan, tetapi teman-temannya cukup simpati kepadanya karena dia adalah tipikal pekerja keras dan selalu bisa diandalkan. Teman-temannya ini juga yang membuat Momo bisa 
melupakan masalah-masalah yang sering menyita pikirannya, terutama tentang kedua orangtuanya yang bekerja sebagai TKI. Momo sangat menggemari olahraga basket, postur tubuhnya yang jangkung membuatnya sangat pas untuk bermain olahraga tersebut. Sayang, dikampungnya olahraga tersebut tidak favorit, sehingga dia justru lebih sering main bola voli atau bulu tangkis.

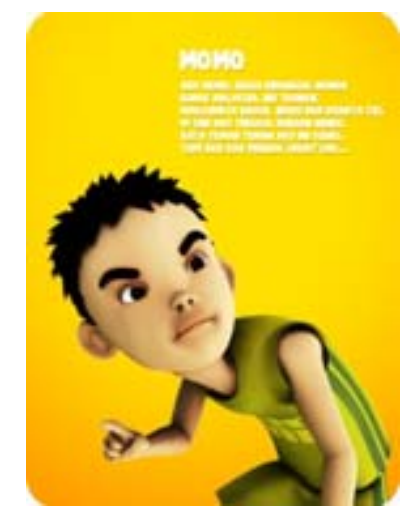

Gambar 7 Karakter Momo

\section{Jingga}

Jingga adalah karakter anak perempuan yang ceria dan cenderung sangat cerewet. Dia berasal dari keluarga yang cukup terpandang dan kaya di desa Maju Makmur (dipertimbangkan bapaknya adalah dokter atau mantri desa). Dia disukai teman-temannya karena sering membawakan oleh-oleh setiap kali dia dan keluarganya pergi ke kota atau selepas berlibur. Namun, dia sering digoda karena kebiasannya yang sangat "higienis" dan cerewet soal kebersihan dan kesehatan. Jingga memiliki kegemaran mengoleksi barang-barang berwarna oranye, bahkan baju sehari-hari yang dikenakannya juga hampir semuanya berwarna oranye atau tone warna tersebut. Jingga sering kali menjadi sasaran yang digoda Bagong.

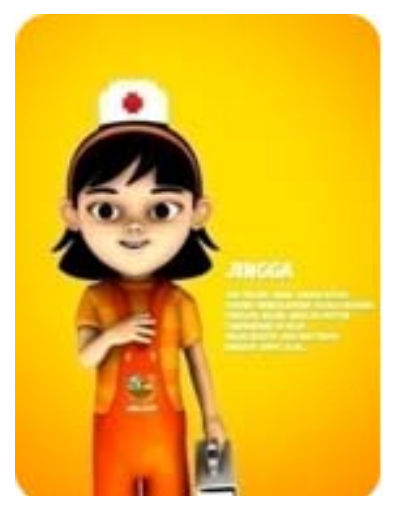

Gambar 8 Karakter Jingga

\section{Laila}

Laila tidak pernah mengenal bapak ibunya. Dia tinggal di panti asuhan dan memiliki karakter cenderung introvert. Sifatnya ini sangat berbeda dengan Jingga yang ceria, tetapi justru hal ini membuat mereka menjadi sangat akrab karena mereka berdua bisa saling mengisi. Laila punya pengetahuan agama yang cukup baik, kebiasannya berdoa dan ikhlas terhadap apapun yang terjadi 
menolong teman-temannya tetap tenang dan tabah menghadapi saat-saat genting. Ketenangan sangat diperlukan untuk mendapatkan solusi terbaik dalam setiap permasalahan.

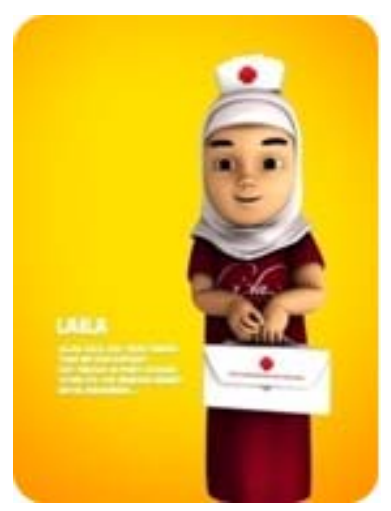

Gambar 9 Karakter Laila

\section{Setting}

Seperti yang telah disinggung sebelumnya, setting cerita ini berada di desa Maju Makmur, representasi imajiner sebuah desa di Jawa (Tengah). Sebagai referensi dan objek survei adalah daerah Muntilan, perbatasan Jogja-Magelang. Berikut adalah foto-foto referensi hasil penelitian langsung ke lapangan, dan bagaimana visual setelah ditransformasikan dalam format CG hasilnya adalah sebagai berikut:
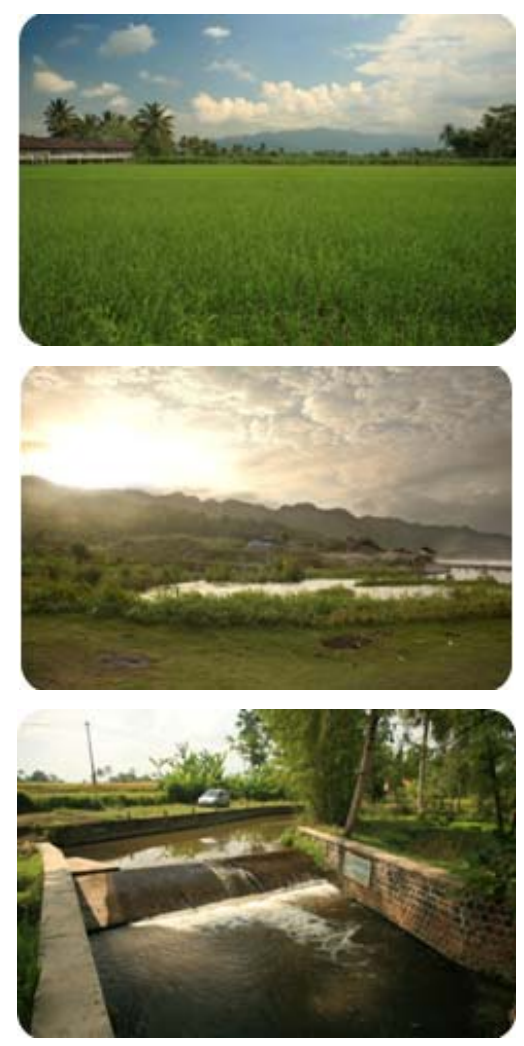
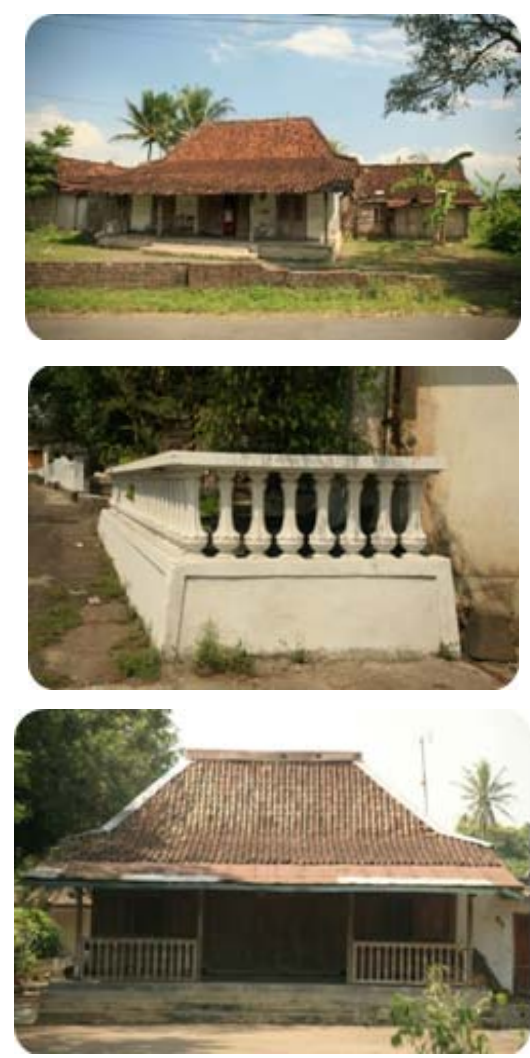

Gambar 10 Hasil Studi Lapangan (Foto oleh Kadek Satria Adidharma) 
Setting setelah dikonversi menjadi objek 3D:

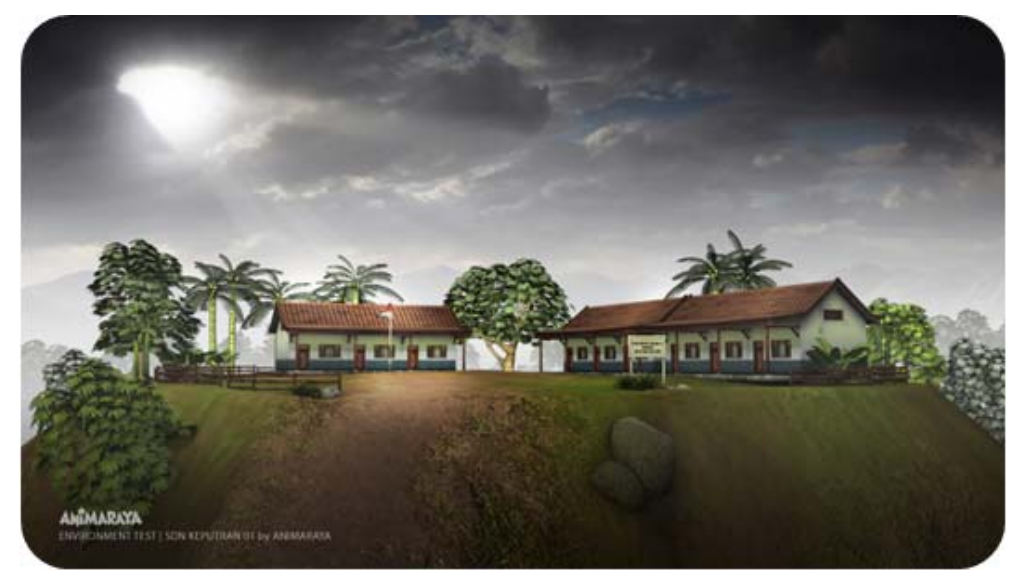

Gambar 11 Setting Sekolah

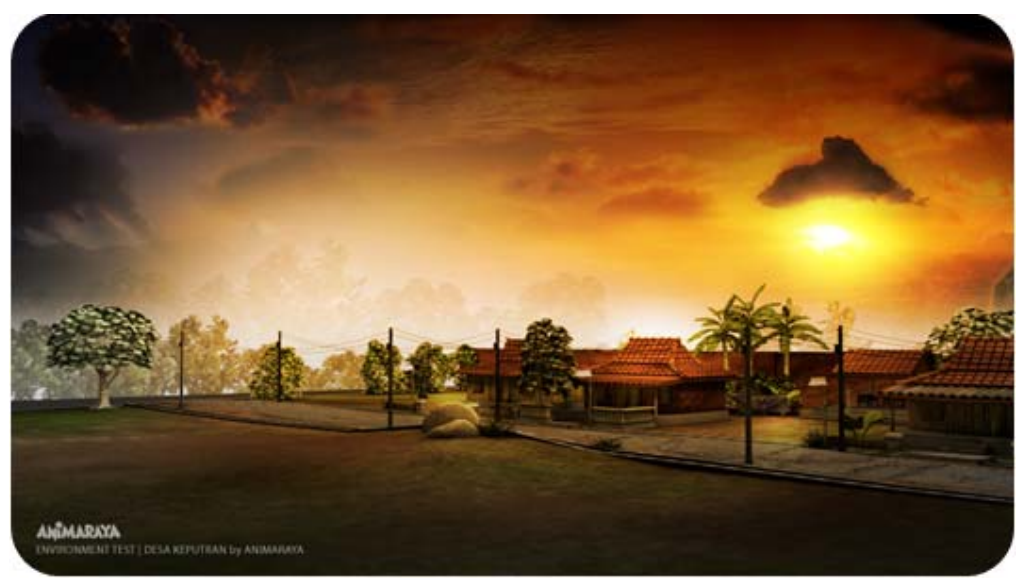

Gambar 12 Setting Pemukiman (Fajar)

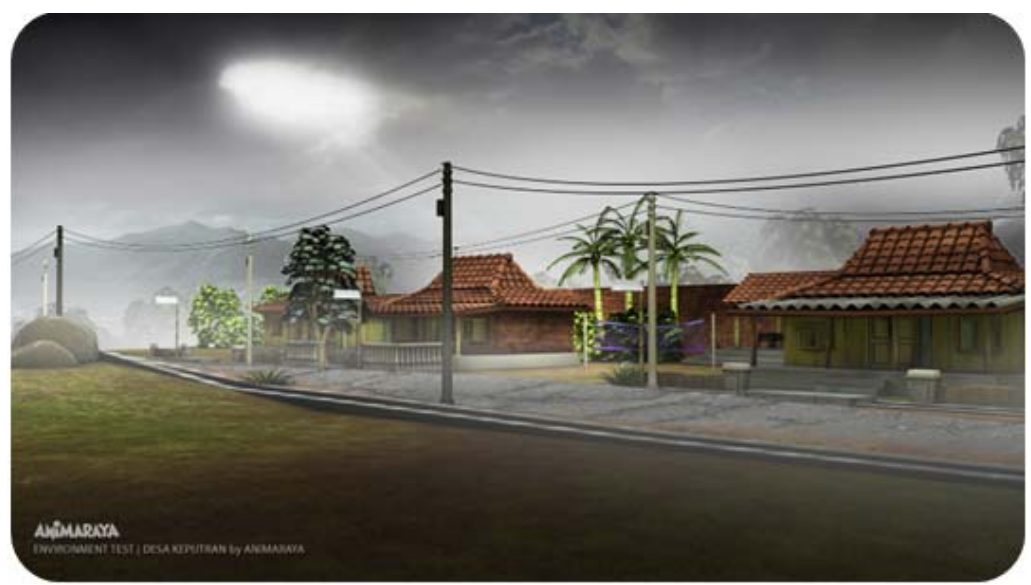

Gambar 13 Setting Pemukiman (Sore) 


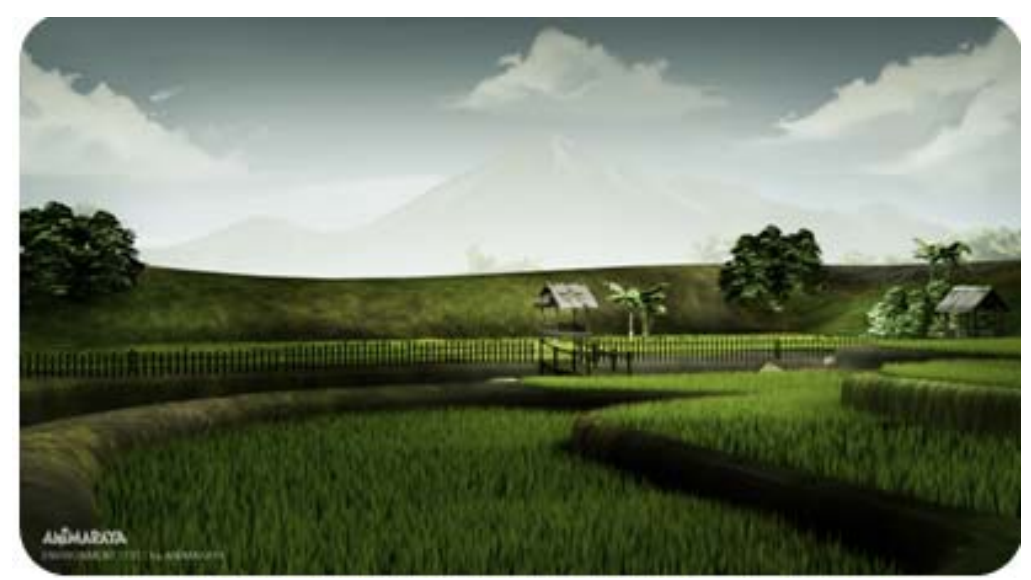

Gambar 14 Setting Persawahan

\section{Screenshot Adegan}

Berikut adalah beberapa adegan dalam serial animasi Jambul episode 1. Di sini jelas ada upaya implementasi prinsip-prinsip fotografi dan sinemaatografi semacam komposisi, warna, depth of field, dan lain-lain.
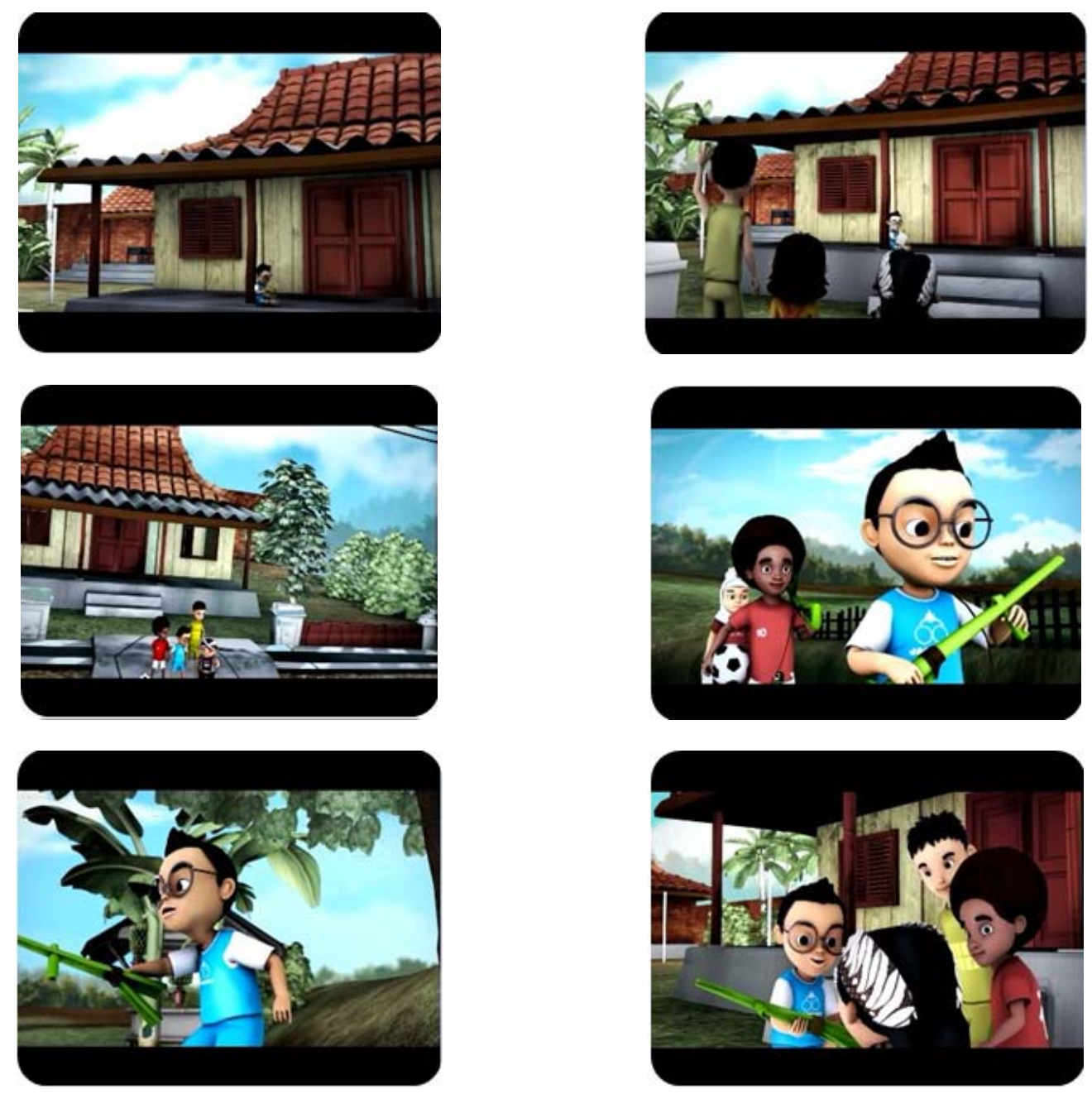

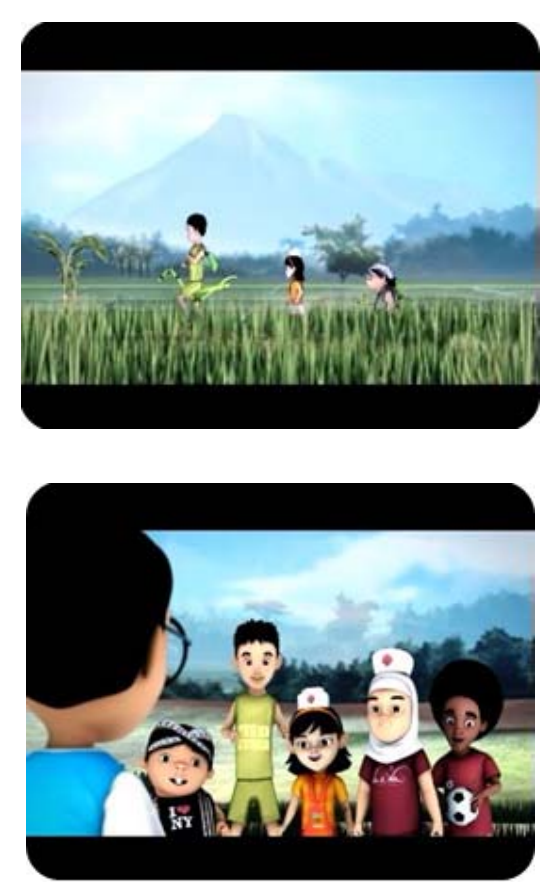
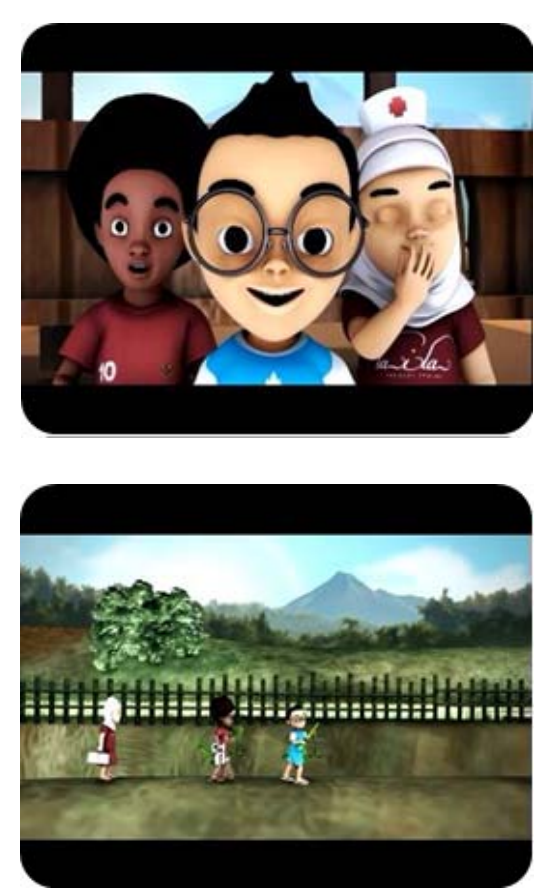

Gambar 15 Screenshot Adegan dalam Episode 1 Jambul

\section{SIMPULAN}

Animasi di Indonesia telah melewati perjalanan panjang. Meskipun belum mampu menjadi tuan rumah di negeri sendiri, geliat dan hasrat menciptakan karya animasi selalu muncul di setiap generasi. Ironisnya, dengan segala sikap abai dan penghargaan yang buruk di dalam negeri, banyak talenta - baik personal maupun lembaga - yang justru meraih prestasi membanggakan di level internasional. Jambul dengan segala keterbatasannya berusaha memberikan bukti bahwa animasi tidak sekadar ide dan cita-cita. Meskipun masih banyak kendala dan kekurangan di sana-sini, kelahiran Jambul adalah upaya yang patut diapresiasi di tengah minimnya produksi serial animasi nasional. Serial animasi idealnya merupakan kerjasama dari berbagai pihak. Seperti layaknya proyek besar, diperlukan sinergi dari banyak disiplin ilmu dan latar belakang. Apa gunanya menonjolkan diri karena skill/keahlian tertentu, tetapi tujuan menciptakan karya animasi tidak pernah terwujud?

\section{DAFTAR PUSTAKA}

Sarris, N. (2005). 3d Modeling and Animation: Synthesis and Analysis Techniques for the Human Body. London: IRM Press.

Scott, L. M. (2003). Persuasive Imagery: A Consumer Response Perspective. London: Lawrence Erlbaum Associates.

Watkins, A. (2001). 3D Animation: From Models to Movies. Massachusetts: Charles River Media. 